\title{
Animal Models Impacted by Phytoestrogens in Commercial Chow: Implications for Pathways Influenced by Hormones
}

\author{
Nadine M. Brown and Kenneth D. R. Setchell \\ Clinical Mass Spectrometry, Children's Hospital Medical Center, Cincinnati, Ohio
}

SUMMARY: It is generally not known that most commercial rodent diets are formulated with soy protein and deliver large daily doses of isoflavones to animals throughout their lifespan, including the in utero period. Here, we demonstrate that isoflavones are bioavailable and show that commercial rodent diets universally used by animal facilities lead to very high steady-state serum isoflavone concentrations in adult rats $(2613 \pm 873 \mathrm{ng} / \mathrm{mL})$ and mice $(2338 \pm 531 \mathrm{ng} / \mathrm{mL})$, exceeding the animal's endogenous estrogen level by 30,000- to 60,000-fold. We demonstrate the maternal-fetal intrauterine transfer of isoflavones in animals fed a standard Purina 5001 soy-containing diet and show that newborn rat pups have high serum isoflavones levels $(540 \pm 174 \mathrm{ng} / \mathrm{mL})$ that are maintained throughout the suckling period by passage of isoflavones into maternal milk. These findings have profound implications for all animal experiments, including multigenerational studies and studies of transgenic animals, especially if biochemical or morphological end-points are influenced by the hormonal or nonhormonal properties of phytoestrogens. These compounds have the potential to modulate genotypic and phenotypic expression in general, and therefore, all investigators should be vigilant to the phytoestrogen composition of commercial rodent diets because there is a history of potent biological effects in larger animals and in humans from high circulating isoflavone concentrations. (Lab Invest 2001, 81:735-747).

$A$ Ithough phytoestrogens are ubiquitous in the plant kingdom, it is soybeans and foods made with purified soy proteins that are by far the greatest contributors of isoflavones to animal and human diets (Coward et al, 1993; Eldridge, 1982; Eldridge and Kwolek, 1983; Franke et al, 1995; Murphy, 1982; Walter, 1941; Walz, 1931; Wang and Murphy, 1994). This class of phytoestrogen has many hormonal and nonhormonal properties capable of modulating cell function. The current clinical and nutritional interest in phytoestrogens (Setchell, 1998; Setchell and Cassidy, 1999) has led to many animal and in vitro studies to better understand the mechanisms of their action, and these studies have invariably been performed in rodents (Adlercreutz et al, 1992; Barnes et al, 1990; Kim et al, 1998; Setchell and Adlercreutz, 1988).

Although it is known that isoflavones are consistently high in the serum and urine of humans who regularly consume soy protein foods (Adlercreutz et al, 1991, 1993b; Morton et al, 1994; Murphy et al, 1982; Setchell et al, 1997, 1998), it is less well appreciated in the scientific community that commercial diets formulated with soy meal (Drane et al, 1975; Murphy, 1982; Thigpen et al, 1999a, 1999b) cause rodents to have sustained high steady-state serum isoflavone concentrations. Such effects have tremendous implications for animal experiments, particularly when biochemical

Received February 6, 2001.

Address reprint requests to: Dr. Nadine M. Brown or Dr. Kenneth D. R. Setchell, Children's Hospital Medical Center, Clinical Mass Spectrometry, 3333 Burnet Avenue, Cincinnati, Ohio 45227.E-mail: brown0@chmcc.org orksetchell@aol.com or morphological end-points are being measured that may be influenced by the hormonal or nonhormonal properties of isoflavones (Boettger-Tong et al, 1998; Drane et al, 1975). Coumestrol, a component of alfalfa (Knuckles et al, 1976) and still present in some commercial rodent diets, influences uterine growth (Ashby et al, 1999; Whitten et al, 1992), accelerates vaginal opening (Whitten and Naftolin, 1992), and causes long-term effects on reproductive cycling and behavior (Whitten et al, 1995). This phytoestrogen has $10^{2}$ fold greater estrogenicity (Bickoff et al, 1962) than soy isoflavones, and major rodent diet manufacturers now offer phytoestrogen-reduced diets that exclude alfalfa as an ingredient. It was pointed out recently that immature rats unwittingly fed a rodent diet formulated with soy-meal and alfalfa had a near maximal uterotrophic stimulation and consequently failed to show the usual biochemical and morphological responses to exogenously administered estradiol (Boettger-Tong et al, 1998). The diet's composition had been reformulated without any notice to researchers using the feed, triggering months of troubleshooting. Additionally, an experiment performed within our own Institute to investigate the anti-inflammatory effects of soy isoflavone genistein using the Carrageenan-induced paw edema rat model of inflammation (SadowskaKrowicka et al, 1998; Salzman et al, 1999) was ruined by the inadvertent feeding of Purina 5001 (Purina, St. Louis, Missouri) diet to the control group of animals, negating the effects of genistein which was being tested. These two specific examples show how dietary phytoestrogens from commercial rodent diets 
can interfere with or distort outcome measures in animal experiments.

Interest in soy and its constituent phytoestrogens was stimulated by the hypothesis that isoflavones play an important role in the prevention of many hormonedependent conditions (Setchell et al, 1984). For example, when adults consume modest amounts of soy protein foods, the serum and urinary concentrations of these isoflavones typically exceed endogenous estradiol concentrations by several orders of magnitude (Adlercreutz et al, 1993b; Setchell, 1998; Setchell and Cassidy, 1999). Similarly, infants fed soy formula have serum isoflavone levels that exceed estradiol by 13,000- to 22,000-fold (Setchell et al, 1997; Setchell et al, 1998). As a result, there has been much interest in the potential beneficial and negative effects of dietary phytoestrogens. This is heightened by the recent Food and Drug Administration (FDA) ruling which allows the food industry to make the claim that foods containing $6.25 \mathrm{~g}$ of soy protein per serving reduce the risk of heart disease because of its hypocholesterolemic effect (Food and Drug Administration, 1999). Although the role of isoflavones in human cancer prevention is yet to be established, the anticancer activity of isoflavones in animal models of cancer is convincing (Adlercreutz et al, 1992; Barnes et al, 1990, 1994; Barnes and Peterson, 1995). Diets fortified with either soy protein or the pure isoflavones reduce tumor formation and influence surrogate markers for tumor risk in animal models of mammary (Barnes et al, 1990; Constantinou et al, 1996; Helferich et al, 1998; Lamartiniere et al, 1995a, 1995b), colon (Bennick et al, 1999), and prostate cancers (Pollard and Luckert, 1997).

Isoflavones appear to be natural selective estrogen receptor modulators (SERMs) because of the manner in which they bind to estrogen receptors, particularly ER $\beta$ (Brzozowski et al, 1997; Pike et al, 1999). They act as partial estrogen agonists (Makela et al, 1995b; Mathieson and Kitts, 1980; Setchell and Adlercreutz, 1988) and antagonists (Lamartiniere and Holland, 1992; Makela et al, 1995c) and have important nonhormonal properties (Adlercreutz et al, 1992; Barnes and Peterson, 1995; Kim et al, 1998; Setchell, 1998). The soybean isoflavone genistein is a potent inhibitor of tyrosine kinases (Akiyama et al, 1987), interferes with cell signal transduction pathways (Kim et al, 1998), and has been found to inhibit several growth factors (Brown et al, 1998; Dalu et al, 1998). These compounds also inhibit the activity of a number of enzymes (Adlercreutz et al, 1993a; Evans et al, 1995; Makela et al, 1995a). Isoflavones have antioxidant activity (Wei et al, 1995), which in vivo has been shown to reduce the susceptibility of lipids to oxidation (Jenkins et al, 2000; Kapiotis et al, 1997; Ruiz-Larrea et al, 1997; Sheiber et al, 1999; Tikkanen et al, 1998) contributing to the overall cardio-protective effects of soy protein by favorably influencing lipid homeostasis (Anderson et al, 1995; Crouse et al, 1999).

Here, we examine for the first time the bioavailability of isoflavones as assessed by their serum and urinary levels in rats and mice fed a number of commonly used commercial rodent diets. Our findings demonstrate alarmingly high serum and urinary concentrations of the isoflavones equol, daidzein, and genistein when adults of both rodent species are fed these diets. Furthermore, we show that dams that are fed one of the most commonly used rodent diets throughout pregnancy, Purina 5001, give birth to pups with high serum isoflavone levels. Also, these pups sustain high serum isoflavone concentrations.

\section{Results}

\section{Phytoestrogen Content of Commercial Rodent Diets}

In the present study, we determined by reverse phase HPLC the isoflavone content of seven commercial rodent diets. Three of these, AIN-76A, AIN-93G, and AIN-93M, had no detectable levels of isoflavones (limits of detection, $5 \mu \mathrm{g} / \mathrm{g}$ diet). The remaining four diets, Purina 5001, Purina 5008, Purina 5010, and the $\mathrm{NIH}-07$, all had substantial amounts of isoflavones. HPLC chromatograms of the four phytoestrogencontaining diets were qualitatively similar. Figure 1 shows a typical chromatographic profile of the Purina 5001 diet (Ralston Purina), revealing the major isoflavones to be the $\beta$-glycoside conjugates, daidzin, and genistin. A relatively small proportion of glycitin was also present. The identity of these isoflavones was conclusively established by mass spectrometry. There

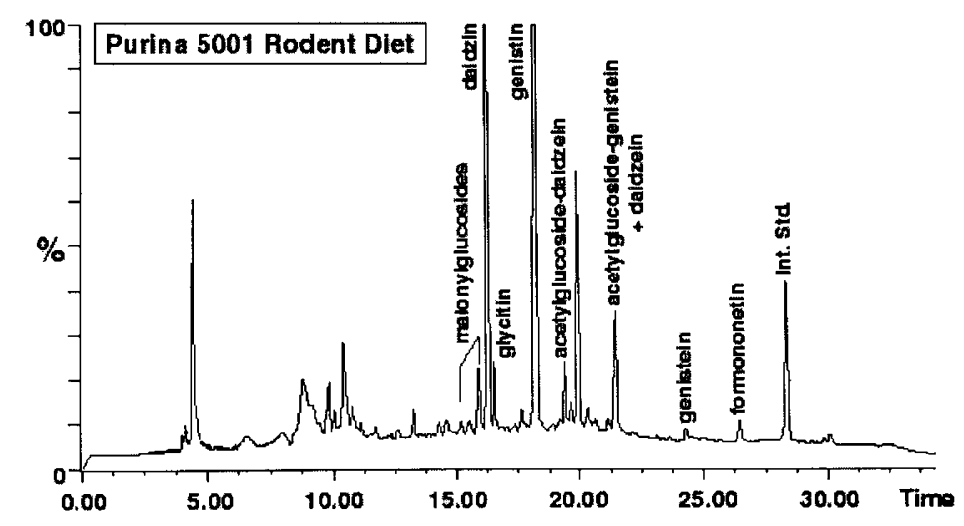

Figure 1.

Reverse-phase HPLC chromatographic profile showing the isoflavone composition of a typical sample of commercial Purina 5001 rodent diet. 
Table 1. Concentration of Individual Isoflavones $(\mu \mathrm{g} / \mathrm{g})$ in Seven Commercial Rodent Diets as Determined by HPLC ${ }^{a}$

\begin{tabular}{lcccrrrr}
\hline & AIN-93G & AIN-93M & NIH-76A & Purina \#5001 & Purina \#5008 & Purina \#5010 & NIH-07 \\
\hline Daidzin & n.d. & n.d. & n.d. & $262 \pm 6$ & $270 \pm 8$ & $221 \pm 10$ & $117 \pm 8$ \\
Daidzein & n.d. & n.d. & n.d. & $59 \pm 1$ & $74 \pm 0$ & $49 \pm 1$ & $30 \pm 0$ \\
Genistin & n.d. & n.d. & n.d. & $318 \pm 2$ & $327 \pm 3$ & $257 \pm 1$ & $160 \pm 2$ \\
Genistein & n.d. & n.d. & n.d. & $4 \pm 0$ & $5 \pm 0$ & $4 \pm 0$ & $3 \pm 0$ \\
Glycitin & n.d. & n.d. & n.d. & $53 \pm 1$ & $49 \pm 1$ & $45 \pm 3$ & $21 \pm 1$ \\
Formononetin & n.d. & n.d. & n.d. & $10 \pm 0$ & n.d. & n.d. & n.d. \\
Biochanin A & n.d. & n.d. & n.d. & n.d. & n.d. & n.d. & n.d. \\
Malonylglucoside-daidzein & n.d. & n.d. & n.d. & $10 \pm 2$ & $14 \pm 1$ & $15 \pm 1$ & $16 \pm 0$ \\
Malonylglucoside-genistein & n.d. & n.d. & n.d. & n.d. & n.d. & n.d. & n.d. \\
Malonylglucoside-glycitein & n.d. & n.d. & n.d. & $16 \pm 2$ & $17 \pm 2$ & $15 \pm 1$ & $9 \pm 0$ \\
Acetylglucoside-daidzein & n.d. & n.d. & n.d. & $55 \pm 2$ & $52 \pm 1$ & $42 \pm 2$ & $31 \pm 3$ \\
Acetylglucoside-genistein & n.d. & n.d. & n.d. & n.d. & n.d. & n.d. & n.d. \\
Acetylglucoside-glycitein & n.d. & n.d. & n.d. & $24 \pm 4$ & $22 \pm 4$ & $17 \pm 2$ & $7 \pm 2$ \\
Glycitein & n.d. & n.d. & n.d. & n.d. & n.d. & n.d. & n.d. \\
Coumestrol & n.d. & n.d. & n.d. & n.d. & n.d. & n.d. & n.d. \\
\hline Totals & n.d. & n.d. & n.d. & $810 \pm 10$ & $829 \pm 9$ & $671 \pm 14$ & $394 \pm 12$ \\
\hline n.d. = not detected. & & & & & & &
\end{tabular}

was no evidence of coumestrol or biochanin $A$, and only a trace of formononetin was found in one of the diets.

Quantitatively, the total isoflavone content of the commercial diets containing soy protein ranged on average from 394 to $829 \mu \mathrm{g} / \mathrm{g}$ (Table 1). Overall, the $\beta$-glycosides, daidzin, and genistin accounted for $70 \%$ to $72 \%$ of the total isoflavones present in all four diets. Smaller amounts of other conjugates and aglycones were also identified. As expected, the isoflavone content of commercial rodent diets was directly proportional to the amount of soy protein in the diets. The daily intake of isoflavones for rats and mice can be calculated from the total isoflavones in a diet (Table 1) multiplied by the average amount of food ingested per day. Based on our measured average food intake of $30 \mathrm{~g}$ for an adult rat and $3 \mathrm{~g}$ for an adult mouse, animals consuming Purina 5001 are exposed to daily intakes of isoflavones of $24.3 \mathrm{mg}$ and $2.4 \mathrm{mg}$, respectively; amounts comparable to those producing a wide range of physiological effects (Table 2).

\section{Serum and Urine Isoflavone Concentrations in Adult Mice Fed Commercial Rodent Diets}

Six groups of adult mice ( $n=4$ per group) were randomized and fed Purina 5008, Purina 5010, NIH07, AIN-76A, AIN-93G, or AIN-93M diets for 2 weeks. The initial body weights of the mice among the groups were not statistically different when analyzed by ANOVA test, and no weight differences were observed after 2 weeks of consuming these diets. Serum and urine isoflavone concentrations in mice are depicted in Figure 2.

In the animals fed phytoestrogen-free AIN-diets, serum concentrations were so low as to be immeasurable, even with the highly sensitive technique of gas chromatography-mass spectrometry (GC-MS) with selected ion monitoring. By contrast, adult mice that had been fed the Purina 5008, Purina 5010, and $\mathrm{NIH}-07$ diets had high serum total isoflavone concentrations; mean \pm SEM values were $2,338 \pm 531 \mathrm{ng} / \mathrm{mL}$, $1,212 \pm 212 \mathrm{ng} / \mathrm{mL}$, and 1,451 $\pm 232 \mathrm{ng} / \mathrm{mL}$, respectively. These values were statistically different from the animals fed the AIN-diets $(p<0.001)$. The bacterially derived metabolite, equol (Axelson et al, 1982; Setchell et al, 1984), was the major isoflavone identified in the serum of all mice fed these three diets and overall accounted for $90 \%$ to $97 \%$ of the total isoflavones in serum. The serum concentrations in animals fed the Purina 5008 diet was almost twice that of the other two diets. These values are at least 30,000-fold higher than the typical serum estrogen concentrations of adult mice, which are 15 to $30 \mathrm{pg} / \mathrm{mL}$ (Barkley et al, 1985; Butcher et al, 1974; Nequin et al, 1979).

The urinary excretion of isoflavones by mice fed the phytoestrogen-rich diets was extremely high, and the profiles mirrored those of the serum (Fig. 2). Total urinary concentrations of isoflavones in the animals fed the Purina 5008, Purina 5010, and NIH-07 diets were $145,813 \pm 26,031 \mathrm{ng} / \mathrm{mL}, 151,374 \pm 35,483$ $\mathrm{ng} / \mathrm{mL}$, and $123,033 \pm 40,817 \mathrm{ng} / \mathrm{mL}$, respectively. In contrast to serum, isoflavones were detected in the urine of animals fed AIN-76A, AIN-93G and, AIN-93M, with total isoflavone concentrations of $5,329 \pm 4781$ $\mathrm{ng} / \mathrm{mL}, 6,212 \pm 795 \mathrm{ng} / \mathrm{mL}$, and 8,175 $\pm 3922 \mathrm{ng} / \mathrm{mL}$, respectively. Equol was the major isoflavone excreted in urine, and there was a proportionally greater amount of daidzein and genistein in the urine when compared with serum.

\section{Serum and Urine Concentrations of Isoflavones in Adult Rats Fed Commercial Rodent Diets}

We compared the serum and urinary concentrations in adult rats fed only the Purina 5001 diet formulated specifically for rats with animals fed the AIN-93G diet. In adult rats fed the Purina 5001 diet the mean \pm SEM 


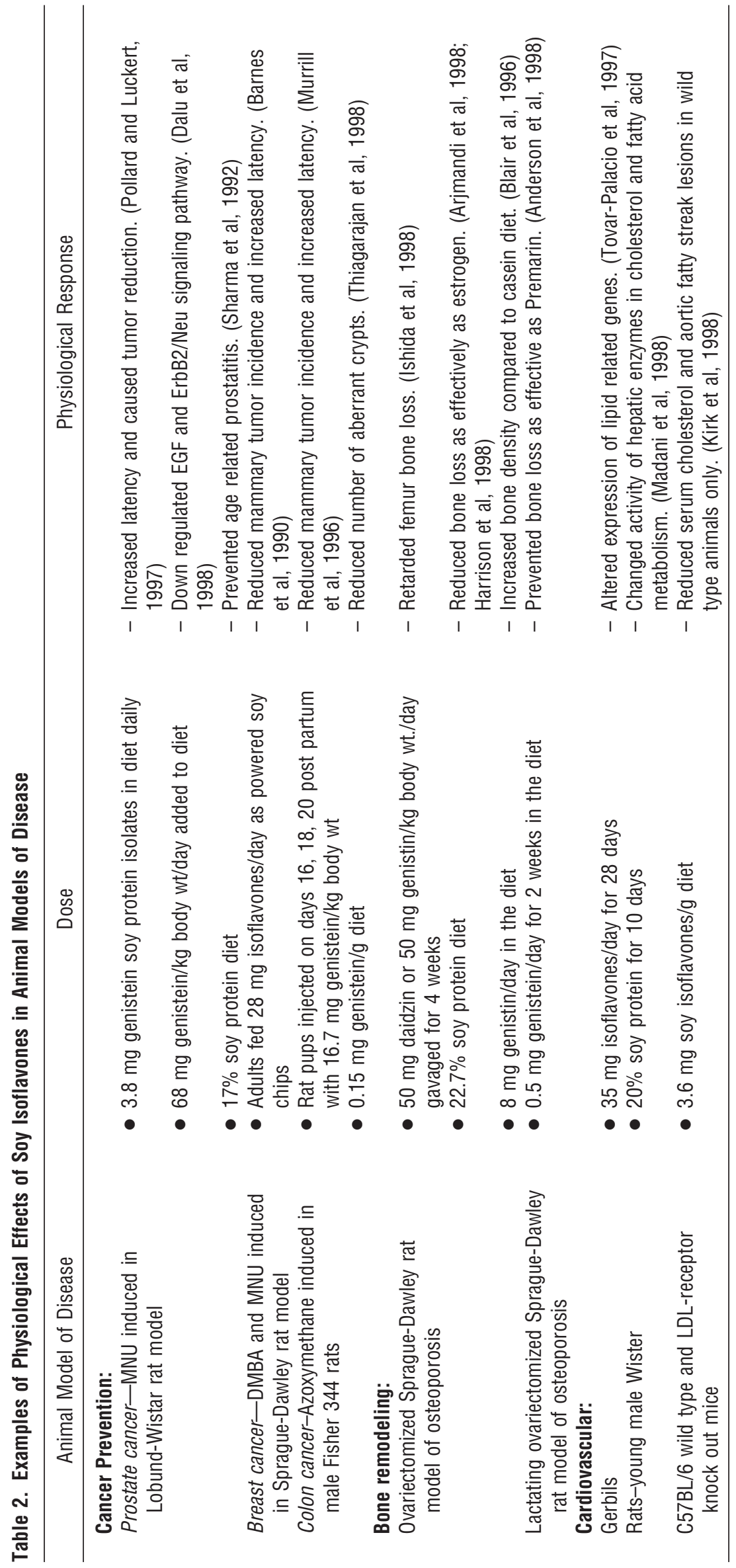


Serum and urine isoflavone concentrations in adult mice fed various soy-containing and soy free commercial rodent diets.

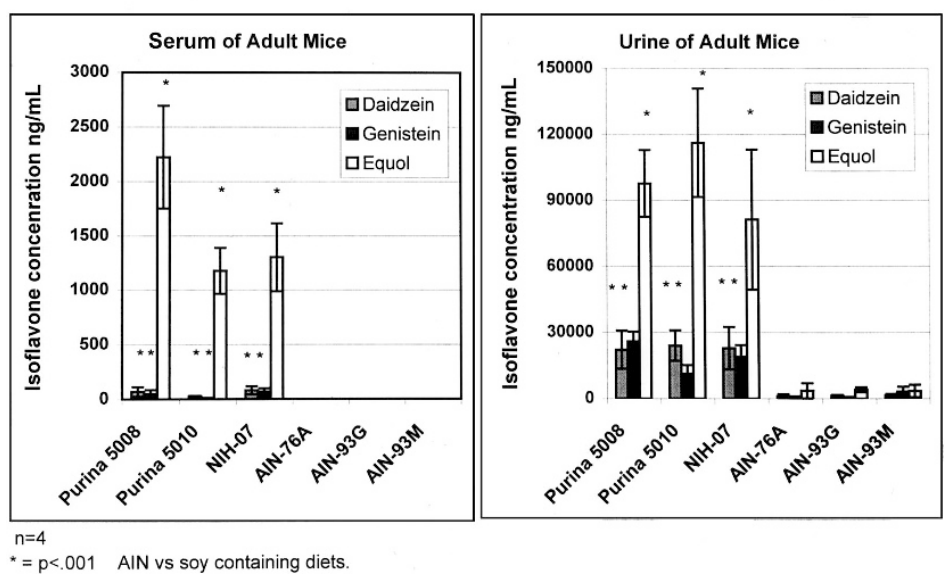

Figure 2.

Serum and urine concentrations (mean \pm SEM in $\mathrm{ng} / \mathrm{ml}$ ) of specific isoflavones in adult mice fed one of six different commercially available diets. *All soy protein containing diets produced serum and urine isoflavone levels significantly higher $(p<.001)$ than diets without soy protein. ( $n=4 / g r o u p)$

serum concentration for total isoflavones was extremely high $(2,613 \pm 873 \mathrm{ng} / \mathrm{mL})$ and statistically different $(p<0.001)$ from that found in rats that were fed an AIN-93G diet (mean \pm SEM, $21 \pm 4 \mathrm{ng} / \mathrm{mL}$ ) (Fig. 3). Equol accounted for $90 \%$ of the total isoflavones in the serum of Purina-fed rats and $71 \%$ of the total isoflavones in AIN-93G-fed rats; albeit the latter concentrations were more than two orders of magnitude lower. Urinary isoflavone concentrations were also very high in Purina 5001-fed rats. Mean \pm SEM total isoflavone concentration in the four animals studied was $80,966 \pm 21,925 \mathrm{ng} / \mathrm{mL}$ compared with $642 \pm 73$ $\mathrm{ng} / \mathrm{mL}$ for the animals fed the AIN-93G diet; the differences being statistically significant $(p<0.001)$. Equol accounted for $52 \%$ of the isoflavones excreted in urine from adults fed Purina diets.

\section{Isoflavone Concentrations in the Stomach Contents and Serum of Nonlactating Newborns and in Serum of Rat Pups Lactating on Dams Fed Commercial Rodent Diets}

To examine the effect of feeding commercial rodent diets to pregnant and lactating rats on their offspring, isoflavone concentrations were measured in the serum of newborn non-suckling pups and nursing pups on days 6,12 , and 16 of age. The serum from male and female pups was analyzed separately. However, because there was no significant gender differences in the serum levels of any of the three isoflavones at any of the time points, data were combined when comparing the two diets. Perhaps worth noting, though, is the fact that the $p$ value for male serum containing more genistein than female serum was $p=0.057$.

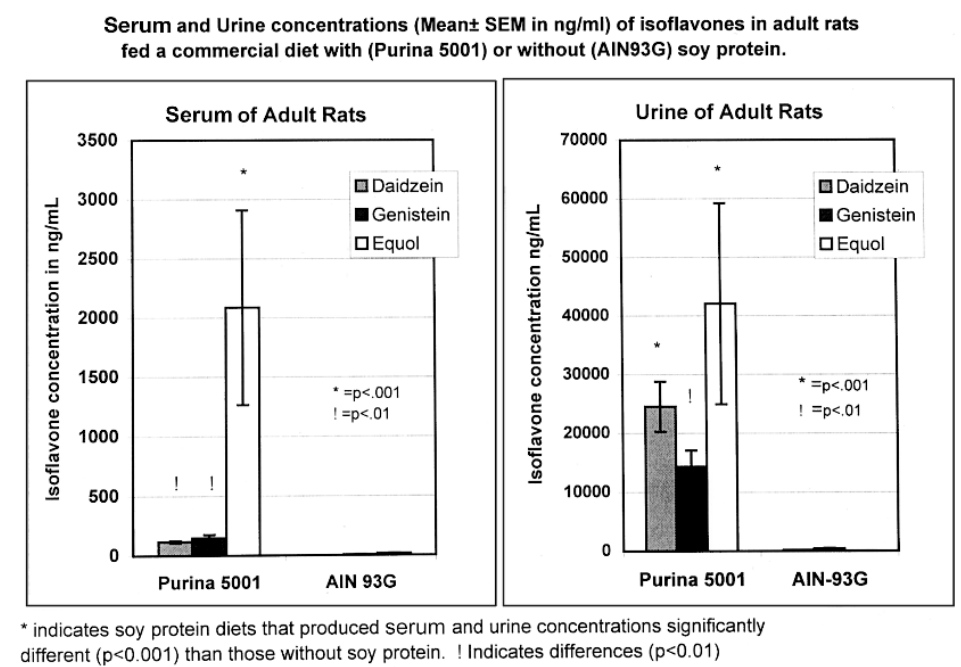

Figure 3.

Serum and urine concentrations (mean $\pm \mathrm{SEM}$ in $\mathrm{ng} / \mathrm{mL}$ ) of isoflavones in adult rats fed a commercial diet with (Purina 5001) or without (AIN-93G) soy protein. * soy protein diets that produced serum and urine isoflavone concentrations significantly different $(p<0.001)$ than those without soy protein; ! differences of $p<$ $0.01, n=4$. 
Values for neither daidzein or equol were close to significance ( $p=0.848$ and 0.402 , respectively). Total serum isoflavone concentrations in rat pups born to or nursing on dams fed soy-free AIN-93G diet were expectedly very low at all ages (Fig. 4). The total isoflavone concentration in the serum of newborn, 6-, 12-, and 16-day-old rat pups was (mean \pm SEM) $19 \pm$ $6 \mathrm{ng} / \mathrm{mL}, 9 \pm 1 \mathrm{ng} / \mathrm{mL}, 8 \pm 1 \mathrm{ng} / \mathrm{mL}$, and $7 \pm 2 \mathrm{ng} / \mathrm{mL}$, respectively. By contrast, total serum isoflavones concentrations in rats born to dams that were fed the Purina 5001 diet were extremely high and showed significant changes over the first 16 days of life (Fig. 4). Isoflavone concentrations were highest in the serum of non-suckled newborns. Equol, the intestinal bacterial metabolite, was the major isoflavone in the newborn. Concentrations decreased significantly $(p<0.001)$ between birth $(540 \pm 174 \mathrm{ng} / \mathrm{mL})$ and day 6 of life $(81$ $\pm 13 \mathrm{ng} / \mathrm{mL}$ ) but remained relatively constant thereafter and through day $16(72 \pm 6 \mathrm{ng} / \mathrm{mL})$. During this period of life, rat pups are suckling and do not consume rodent chow until reaching the age of 15 to 16 days when their eyes open. The source of the isoflavones in the serum of newborn rat pups is therefore of maternal origin. The very high isoflavone concentrations in the serum of rat pups immediately at birth and before any suckling has occurred is explained by prenatal accumulation of isoflavones from maternal-fetal transfer throughout gestation. This is confirmed by analysis of the stomach contents of the non-suckling newborns. This fluid is presumed to contain amniotic fluid swallowed in utero. The stomach contents of the pups delivered by Purina 5001-fed dams had a mean total isoflavone concentration that was extremely high (903 $\pm 255 \mathrm{ng} / \mathrm{mL})$ and was composed of $44 \%$ genistein, $37 \%$ equol, and $19 \%$ daidzein. The corresponding value for the stomach contents of newborns delivered by dams that had been fed the AIN-93G diet throughout pregnancy was $19 \pm 5 \mathrm{ng} / \mathrm{mL}$ and negligible by comparison.

\section{Discussion}

Despite several key reports highlighting the potency of dietary phytoestrogens in a number of large domestic and captive animal species (Bennetts et al, 1946; Setchell et al, 1987a), manufacturers still formulate rodent diets with soy meal, and in some instances the incorporation can be quite high. The use of such diets by animal suppliers means that many animals will have been subjected to multigenerational exposure to phytoestrogens, which may reduce or enhance the sensitivity of the animal to an estrogen, influence phenotype, or modulate the sensitivity of a variety of genomic and non-genomic pathways. For example, there is impressive evidence in the rodent model of chemically-induced breast cancer that genistein given subcutaneously or orally to prepubertal and neonatal female rats leads to a reduced sensitivity to administered carcinogen when the animal reaches adult size (Fritz et al, 1998; Lamartiniere et al, 1995a; Lamartiniere et al, 1998b; Murrill et al, 1996). The effect is an increase in the latency period for tumor appearance and a decrease in tumor burden. Apparently direct actions of isoflavones on breast morphology caused increased differentiation of the terminal end-buds to lobules (Lamartiniere et al, 1998a). Additionally phytoestrogens have been shown to modulate epidermal growth factor (EGF) and the EGF-receptor; an effect which may have implications in tumor development (Brown et al, 1998). Similarly, studies of exposure of male animals to genistein have demonstrated effects on prostate volume and serum testosterone levels (Weber et al, 2000).

We report that universally used commercial rodent diets deliver levels of isoflavones that are consistent with dose ranges known to have physiologic effect in numerous animal models of human disease (Table 2). Given the wide-ranging biologic properties of isoflavones, caution is warranted when designing studies of pathways involved in cell-signaling and gene expres-

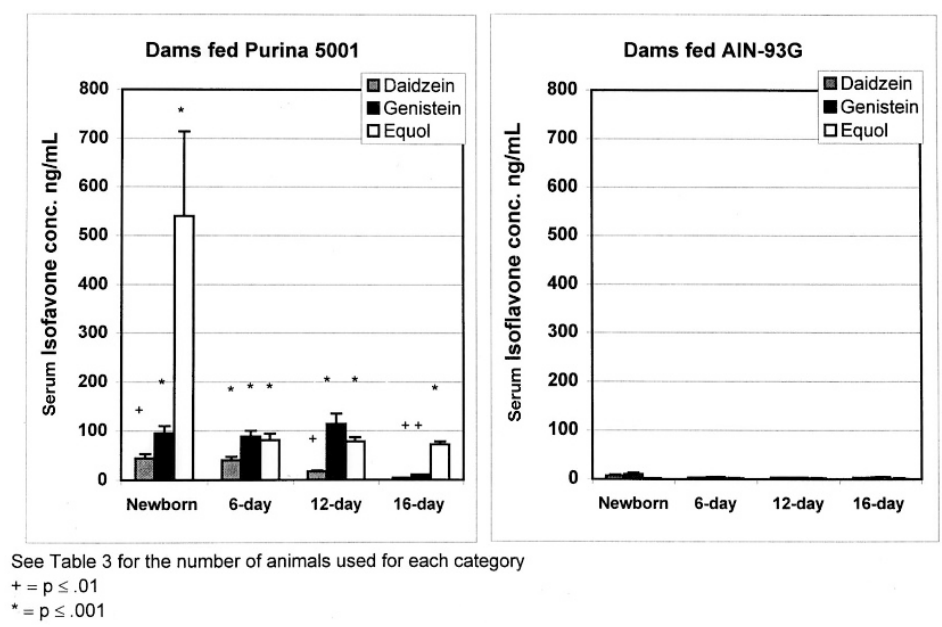

Figure 4.

Serum isoflavone concentrations in newborn non-suckled rat pups immediately on birth and in rat pups of different ages that were suckling on dams fed either a Purina 5001 soy meal containing diet (left panel) or an AIN93-G diet with no phytoestrogens (right panel). 
sion (Kim et al, 1998), especially where animals have been raised on commercial diets containing soy protein, as seems to be the case for most animal husbandry facilities. However, many scientists perform experiments in animal models unaware that the most commonly used rodent diets contain isoflavones at levels that have the potential to influence their experimental end-points. Studies of hormone-dependent conditions, including animal models of cancer, and investigations of potential endocrine-disrupting compounds may be seriously compromised by high dietary phytoestrogen exposure.

Despite the fact that our previous studies using diets containing $20 \%$ soy protein had no significant effect on uterine weight or estrus cycling in adult rats (Barnes et al, 1990) or on anogenital distances, time of vaginal openings, estrus cycle length, or time of testes descent in rats perinatally exposed to genistein (Fritz et al, 1998), the significance of isoflavones in commercial rodent diets is not diminished. In Fritz et al, significant differences were seen in dimethylbenzene $(\alpha)$ anthracene induction of mammary tumors despite lack of impact of reproductive perimeters. Additionally in our recent studies of LongEvans rats fed a Teklad diet containing $600 \mu \mathrm{g}$ isoflavones/g diet, the volumes of the sexually dimorphic nucleus in the brain were altered and reproductive cyclicity was unaffected (Lund et al, submitted). Unfortunately, the measure of estrogenicity of a compound is often assessed only by its effect on the reproductive system. However, the effect of estrogen on numerous other physiologic systems is well documented, and this limited approach underestimates the effect that estrogen-like compounds have on other biological systems, particularly at the biochemical and molecular level.

A recent report evaluated the estrogenic potency of 12 commercially available rodent diets (Thigpen et al, 1999a), three of which were analyzed in this study. In all but two, significant amounts of daidzein and genistein were identified after hydrolysis of extracts of the diets. The concentrations ranged from 69 to 491 $\mu \mathrm{g} / \mathrm{g}$, being equivalent to 0.6 to $4.3 \mathrm{mg} / \mathrm{kg}$ diethylstilbestrol (Thigpen et al, 1999a). These values are consistent with those we report here for four commercial soy-containing diets that had total isoflavone concentrations averaging 394 to $829 \mu \mathrm{g} / \mathrm{gram}$. Isoflavones in the rodent diets are present mainly as glycosides, and hydrolysis of the glycoside moiety is necessary to ensure bioavailability because there is no evidence for absorption of intact isoflavone glycosides. This hydrolysis takes place in the intestine by the action of $\beta$-glucosidases (Axelson et al, 1984; Borriello et al, 1985; Day et al, 1998; Setchell et al, 1984). The aglycones and other bacterially derived metabolites are then absorbed and conjugated mainly to glucuronic acid and undergo enterohepatic recycling (Setchell, 1998). Isoflavones share this feature of their physiology with endogenous estrogens (Adlercreutz, 1962; Adlercreutz and Martin, 1980; Setchell, 1998).

We have for the first time measured the serum concentrations of isoflavones in rats and mice fed these commercial diets and show values to be even higher than the serum concentrations of pure genistein found to influence EGF and ErbB2/Neu signaling pathways and inhibit tumor growth in animal models of prostate and breast cancer (Brown et al, 1998; Dalu et al, 1998). In both species of rodents equol, not daidzein or genistein, was the major isoflavone in serum and urine. Equol was first isolated from rat urine two decades ago, characterized by mass spectrometry (Axelson et al, 1982; Axelson and Setchell, 1981), and its origin was found to be soy meal used in the manufacture of the rodent chow (Axelson et al, 1984). It was shown subsequently to be a specific intestinal bacterial metabolite of the soy isoflavones, daidzin and daidzein (Borriello et al, 1985; Setchell et al, 1984). Our finding that equol accounts for $95 \%$ to $97 \%$ of the measured isoflavones in mouse serum indicates that mice also very efficiently biotransform ingested soy isoflavones. This biotransformation does not reduce the biological potency of phytoestrogens in soy protein because equol shows more than a one order of magnitude greater affinity for the estrogen receptor than its precursor in soy protein (Kuiper et al, 1998a, 1998b). Furthermore, although estradiol is mainly bound to serum sex hormone-binding globulin and albumin, isoflavones are less avidly bound to serum proteins, making them more available for receptor occupancy (Nagel et al, 1998), which should potentially magnify their effectiveness. Overall, the mean serum concentrations of isoflavones measured in adult rodents fed the commonly used commercial rat-specific Purina 5001 diet or the 5010 mouse diet exceed the endogenous estrogen levels $30,000-$ to 60,000 -fold.

Data presented here conclusively demonstrate that the neonatal suckling rat is exposed to high doses of isoflavones from commercial diets fed to its lactating dam. The average amount of food consumed daily by a lactating dam during the 21 days of nursing ranges from 40 to $60 \mathrm{~g}$; hence, 32 to $48 \mathrm{mg}$ of isoflavones are consumed each day from a Purina 5001 diet. The dam is consequently exposed to approximately 90 to 140 $\mathrm{mg}$ isoflavones/kg body weight/day, which is a substantial dose. For comparison, the average intake of isoflavones by humans consuming modest amounts of soy foods is 0.5 to $1.5 \mathrm{mg} / \mathrm{kg}$ body weight (Setchell et al, 1997), and even at these levels endocrine effects are observed (Cassidy et al, 1994). Serum concentrations of isoflavones in suckling rats are high and relatively constant during the suckling period, and their origin is maternal milk. It was recently shown that the stomach contents of 7-day-old neonatal rat pups nursing on dams fed a diet spiked with pure genistein (250 mg/kg body weight) contained high levels of isoflavones (Fritz et al, 1998), and the transfer of isoflavones into human breast milk following consumption of soy foods has already been established (Franke et al, 1995; Setchell et al, 1998). However, it is apparent during development that the highest level of exposure must occur in fetal life, as evidenced by the high serum concentration (total isoflavones, $678 \pm$ $165 \mathrm{ng} / \mathrm{mL}$ ) in the non-suckled offspring immediately at birth. The timing of exposure to estrogen-like substances may be critically important for influencing the 
susceptibility to disease later in life (Brown et al, 1998; Lamartiniere et al, 1995a; Murrill et al, 1996). Our findings of high circulating concentrations of isoflavones in immature rats that suckle dams fed phytoestrogen-rich diets has profound implications for rodent experiments, particularly models of carcinogenesis, or diseases implicating hormone-dependent outcomes. Investigators may not be fully aware when purchasing timed-pregnant females or other rodents whether prior or maintenance diets fed to the animals contained phytoestrogens. Industry's move toward certifying the phytoestrogen content of rodent diets is clearly warranted, as is the more general use, by animal suppliers and investigators, of commercial rodent diets free of phytoestrogens because their biological potency may modify responses in many genomic and non-genomic pathways both in vitro and in vivo.

\section{Materials and Methods}

\section{Animals}

Rats and mice used in this study were housed in an AAALAC-accredited facility that meets or exceeds the Animal Welfare Act requirements, and the study protocol was approved by the Children's Hospital Research Foundation's Animal Use Committee.

\section{Studies in Adult Rodents}

Five- to six-week-old female FVB/N mice were obtained from Charles River Breeding Laboratories (Raleigh, North Carolina) and housed four per cage in climate controlled conditions at $74^{\circ} \mathrm{C}$ with a 12-hour light-dark cycle. Female Sprague Dawley rats from the same supplier were housed two per cage under the same climate conditions. Animals were allowed to acclimate for 1 week after shipment, weighed, and then distributed randomly to give six groups of four mice per group and two groups of four rats per group. Each group of animals was fed at random one of seven different commercially available rodent diets for a 2-week period. The mice were fed Purina 5008, Purina 5010, NIH-07, AIN-76A, AIN-93G, or AIN-93M diet, and the rats were fed Purina 5001 or AIN-93G diet. The first three diets were obtained from Cincinnati Laboratory Supplies in Cincinnati, Ohio, and the others were obtained from Dyets Inc. in Bethlehem Pennsylvania. All animals were supplied water ad libitum during the experiment. After 2 weeks on their respective diets, the animals were weighed and a urine samples were obtained. The animals were then anesthetized with $2 \%$ Isoflurane, and blood samples were obtained by intracardiac puncture. Blood was allowed to clot at room temperature and centrifuged at 3000 rpm for 10 minutes. Serum was then collected. All samples were stored at $-20^{\circ} \mathrm{C}$ until analyzed. Urine was obtained by placing the animals in metabolic cages for 8 to 16 hours.

\section{Studies in Postnatal Rats}

To determine whether rat pups are exposed to phytoestrogens in utero and while suckling on dams fed commercial rodent diets, we measured isoflavone concentrations in the blood of newborn and neonatal suckling rat pups of different ages. Seven 70-day-old virgin female Sprague Dawley rats were obtained from Charles Rivers Laboratory and bred in house by proven Sprague Dawley males from the same supplier. After breeding, they were housed individually. During breeding, gestation and nursing dams were supplied with either Purina 5001 rat chow (3 dams) or AIN-93G (4 dams) ad libitum. Housing conditions were as described above for mice. Dams were monitored near the time of delivery, and non-suckled newborn pups were removed from each litter, leaving the rest of their litter mates to suckle for 6,12 , or 16 days. Blood from decapitated newborn and 6-day-old pups was pooled as necessary to produce a sufficient volume of blood for analysis. However, blood from the two sexes was kept separate; only male blood was pooled with male blood and likewise with females to permit determination of possible sex-related differences in isoflavone absorption. The number of animals used and the samples generated are presented in Table 3. In addition to blood, clear amniotic fluid that had been ingested by the newborn pups in utero was removed from their stomachs for analysis immediately after delivery.

Diet Analysis. Total and individual isoflavones were determined in duplicate samples of each of the diets by reverse phase HPLC and mass spectrometry essentially as described by Setchell et al (Setchell et al, 1987b) and modified by Coward et al (Coward et al, 1993). Each diet was finely ground with a mortar and pestle, and 5.0-g portions were twice extracted into 50 $\mathrm{mL}$ of $80 \%$ methanol by reflux for 1 hour. The sample was filtered and the combined methanolic extract made up to $100 \mathrm{~mL}$. The internal standard, equilenin (60 $\mu \mathrm{g}$ in methanol) was added to a $2 \mathrm{~mL}$ aliquot (1/50th) of the methanolic extract, and lipids were removed by partitioning with vortex into hexane $(2 \times 2$ $\mathrm{mL}$ ). Following centrifugation, the upper hexane layer was removed with a Pasteur pipette and discarded. The methanolic phase was taken directly for analysis by HPLC.

Isoflavones and their conjugates were separated by reverse-phase HPLC on a $25 \times 0.46-\mathrm{cm}$ Aquapore (C8; particle size, $7 \mathrm{~mm}$ ) column under gradient elution conditions essentially as described previously (Coward et al, 1993). The mobile phase (flow rate, 2 $\mathrm{mL} / \mathrm{min}$ ), consisted of an initial isocratic period of 2 minutes of $100 \%$ of a $0.1 \%$ solution of trifluoracetic acid followed by a gradient increasing over a 15minute period to $100 \%$ of a solution of $46.4 \%$ acetonitrile in $0.1 \%$ trifluoracetic acid. A $10 \mu \mathrm{L}$ sample of the extract was injected onto the column, and the individual isoflavones were detected by their absorption at $260 \mathrm{~nm}$ and quantified by their response relative to the internal standard. The between-batch precision of the method, expressed as coefficient of variation as de- 
Table 3. A Summary of the Number of Animals Used and the Number of Samples Produced for GC-MS Analysis of Plasma in Newborn Pups and Pups of 6, 12, and 16 Days Post Partum

\begin{tabular}{|c|c|c|c|c|c|c|c|c|}
\hline & \multicolumn{4}{|c|}{ Purina 5001} & \multicolumn{4}{|c|}{ AIN93G } \\
\hline & \multicolumn{2}{|c|}{ Males } & \multicolumn{2}{|c|}{ Females } & \multicolumn{2}{|c|}{ Males } & \multicolumn{2}{|c|}{ Females } \\
\hline & $\begin{array}{l}\text { No. of } \\
\text { animals } \\
\text { used }\end{array}$ & $\begin{array}{c}\text { No. of } \\
\text { samples } \\
\text { produced }\end{array}$ & $\begin{array}{l}\text { No. of } \\
\text { animals } \\
\text { used }\end{array}$ & $\begin{array}{c}\text { No. of } \\
\text { samples } \\
\text { produced }\end{array}$ & $\begin{array}{l}\text { No. of } \\
\text { animals } \\
\text { used }\end{array}$ & $\begin{array}{c}\text { No. of } \\
\text { samples } \\
\text { produced }\end{array}$ & $\begin{array}{l}\text { No. of } \\
\text { animals } \\
\text { used }\end{array}$ & $\begin{array}{c}\text { No. of } \\
\text { samples } \\
\text { produced }\end{array}$ \\
\hline Newborns & 7 & 2 & 15 & 4 & 12 & 3 & 13 & 3 \\
\hline 6-day pups & 14 & 7 & 14 & 7 & 13 & 6 & 18 & 9 \\
\hline 12-day pups & 11 & 11 & 13 & 13 & 9 & 9 & 7 & 7 \\
\hline 16 -day pups & 6 & 6 & 5 & 5 & 6 & 6 & 4 & 4 \\
\hline
\end{tabular}

termined from replicate analyses $(n=16)$, ranged from $5.4 \%$ to $6.1 \%$ for total isoflavones in two different food samples having concentrations of $500 \mu \mathrm{g} / \mathrm{g}$ and $24,000 \mu \mathrm{g} / \mathrm{g}$.

\section{Serum and Urine Analysis}

Isoflavones in adult rat and mouse serum and newborn and suckling rat pups were measured by selected ion monitoring GC-MS using stable-isotopic labeled internal standards $\left[{ }^{13} \mathrm{C}\right]$ genistein and $\left[{ }^{13} \mathrm{C}\right]$ daidzein [synthesized previously (Baraldi et al, 1999; Setchell et al, 1997)] to quantify serum daidzein and genistein concentration. Equol was measured relative to the $\left[{ }^{13} \mathrm{C}\right]$ daidzein internal standard after correction for isotopic contributions from daidzein.

Serum $(0.25$ to $0.5 \mathrm{~mL})$ was equilibrated with $50 \mathrm{ng}$ of the internal standards, $\left[{ }^{13} \mathrm{C}\right]$ daidzein and $\left[{ }^{13} \mathrm{C}\right]$ genistein $(1 / 50 \mu \mathrm{L}$ of a $1.0 \mathrm{mg} / \mathrm{mL}$ solution of each in methanol). The serum was then diluted with 10 volumes of $0.5 \mathrm{M}$ triethylamine sulfate $\left(\mathrm{pH} \mathrm{5.0)}\right.$ ) and heated to $65^{\circ} \mathrm{C}$ for 30 minutes. Isoflavones were extracted from the diluted serum sample by passage through a solid-phase C18Bond Elut cartridge that had been pre-washed sequentially with $5 \mathrm{~mL}$ of methanol, $5 \mathrm{~mL}$ of distilled water, and $5 \mathrm{~mL}$ of warm triethylamine sulfate. Isoflavones were eluted from the cartridge with $5 \mathrm{~mL}$ of methanol at room temperature. This methanolic extract was taken to dryness. Then, $0.5 \mathrm{M}$ sodium acetate buffer $(2 \mathrm{~mL} ; \mathrm{pH} 4.5)$ was added, and isoflavone conjugates were enzymatically hydrolyzed at $37^{\circ} \mathrm{C}$ overnight with 2000 units of mixed $\beta$-glucuronidase and sulfatase preparation, Helix pomatia (Pharmindustrie, L'Industrie Biologique, Francaise, Clichy, France). Because Helix pomatia naturally contains small amounts of isoflavones, they are first removed by passing the enzyme solution through a C18-Bond Elut cartridge to avoid contamination of the samples. After hydrolysis isoflavones were isolated by solid-phase extraction on a C18-Bond Elut cartridge and recovered by elution with methanol $(5 \mathrm{~mL})$. The methanolic extract was diluted to $80 \%$ by the addition of water and then passed through a small column bed $(7 \mathrm{~cm} \times$ $0.4 \mathrm{~cm}$ ) of the lipophilic anion exchange gel, triethylaminohydroxypropyl Sephadex LH-20, prepared in the hydroxide form in $80 \%$ methanol column (Axelson and Setchell, 1980). This gel affords separation of neutral compounds, which pass directly through the gel, from phenolics, which are retained (Axelson and Setchell, 1981). After elution of the neutral compounds with $80 \%$ methanol, the column was washed with $5 \mathrm{~mL}$ of chloroform/methanol (1:1 by volume), and this was discarded. Phenolic compounds, including the isoflavones, were recovered by eluting the gel with $15 \mathrm{~mL}$ of methanol saturated with $\mathrm{CO}_{2}$ gas. This fraction was taken to dryness under a stream of nitrogen gas, and the isoflavones were converted to their tert-butyldimethylsilyl (t-BDMS) ether derivatives by addition of acetonitrile $(100 \mu \mathrm{L})$ and $\mathrm{N}$-methyl-N-t-butyldimethylsilyltrifluoroacetamide in 1\% t-butyldimethylchloro-silane (100 $\mu \mathrm{L}$; Regis Technologies, Inc., Morton Grove, Illinois) and heating at $65^{\circ} \mathrm{C}$ for 2 hours. The reagents were removed by evaporation in a stream of nitrogen, the derivatives were dissolved in hexane (100 $\mu \mathrm{L})$, and 1 to $2 \mu \mathrm{L}$ were injected on a column for analysis by GC-MS.

Gas Chromatography-Mass Spectrometric Conditions. Isoflavone t-BDMS ethers were rapidly separated by chromatography on a short DB-1 fused silica capillary column [( $2 \mathrm{~m} \times 0.25 \mathrm{~mm}$ i.d.; film thickness, $0.25 \mu \mathrm{m}$ (J \& W Scientific Inc., Folsom, California)] with helium as the carrier gas (flow-rate, approximately 2 $\mathrm{mL} / \mathrm{min}$ ) and by temperature programming from $260^{\circ} \mathrm{C}$ to $310^{\circ} \mathrm{C}$ with increments of $10^{\circ} \mathrm{C} / \mathrm{min}$. The eluting components were ionized by electron ionization $(70 \mathrm{eV})$ and mass spectrometric detection of isoflavones was achieved with selected ion monitoring of the specific ions of $\mathrm{m} / \mathrm{z} 425(\mathrm{M}-57$ in daidzein and the internal standard), m/z 555 (M-57 in genistein) and $\mathrm{m} / \mathrm{z} 470\left(\mathrm{M}^{+}\right.$of equol). These ions are highly specific for these metabolites. The corresponding $\left[{ }^{13} \mathrm{C}\right]$ daidzein and $\left[{ }^{13} \mathrm{C}\right]$ genistein internal standards were detected from the corresponding shift in masses at $\mathrm{m} / \mathrm{z}$ 426 and $\mathrm{m} / \mathrm{z} 556$ respectively. The individual isoflavones were quantified by comparing the peak area responses obtained for each isoflavone (detected in the specific ion channels at the correct retention time determined from authentic compounds) with the peak area response for the internal standard. The area ratio was interpolated against calibration curves constructed for known amounts (0 to $100 \mathrm{ng}$ ) of the individual isoflavones and corrected for the natural isotopic interference across the different channels. 
Concentrations are expressed as $\mathrm{ng} / \mathrm{mL}$ for the individual serum isoflavones, and similar units for urine.

\section{Urinary Isoflavone Analysis}

Urinary isoflavones were determined in exactly the same manner as serum isoflavones except that the initial solid-phase extraction step was omitted. Urine (100 $\mu \mathrm{L})$ was diluted with $5 \mathrm{~mL}$ of acetate buffer and hydrolyzed overnight at $37^{\circ} \mathrm{C}$ with a mixed $\beta$-glucuronidase sulfatase preparation of Helix pomatia. The hydrolysis conditions and subsequent steps of the methodology were exactly as described above for serum. Urinary isoflavones were converted to the t-BDMS ether derivatives and quantified by GC-MS.

\section{References}

Adlercreutz H (1962). Studies on oestrogen excretion in human bile. Acta Endocrinol Suppl (Copenh) 72:1-220.

Adlercreutz H, Bannwart C, Wahala K, Makela T, Brunow G, Hase T, Arosemena PJ, Kellis JT, and Vickery LE (1993a). Inhibition of human aromatase by mammalian lignans and isoflavonoid phytoestrogens. J Steroid Biochem Mol Biol 44:147-153.

Adlercreutz $\mathrm{H}$, Fotsis $\mathrm{T}$, Lampe J, Wahala K, Makela T, Brunow G, and Hase T (1993b). Quantitative determination of lignans and isoflavonoids in serum of omnivorous and vegetarian women by isotope dilution gas chromatographymass spectrometry. Scand J Clin Lab Invest Suppl 215:5-18.

Adlercreutz $\mathrm{H}$, Honjo $\mathrm{H}$, Higashi A, Fotsis $\mathrm{T}$, Hamalainen $\mathrm{E}$, Hasegawa T, and Okada H (1991). Urinary excretion of lignans and isoflavonoid phytoestrogens in Japanese men and women consuming a traditional Japanese diet. Am J Clin Nutr 54:1093-1100.

Adlercreutz H and Martin F (1980). Biliary excretion and intestinal metabolism of progesterone and estrogens in man. J Steroid Biochem 13:231-244.

Adlercreutz H, Mousavi Y, Clark J, Hockerstedt K, Hamalainen E, Wahala K, Makela T, and Hase T (1992). Dietary phytoestrogens and cancer: In vitro and in vivo studies. J Steroid Biochem Mol Biol 41:331-337.

Akiyama T, Ishida J, Nakagawa S, Ogawara H, Watanabe S, Itoh N, Shibuya M, and Fukami Y (1987). Genistein, a specific inhibitor of tyrosine-specific protein kinases. J Biol Chem 262:5592-5595.

Anderson JJ, Ambrose WW, and Garner SC (1998). Biphasic effects of genistein on bone tissue in the ovariectomized, lactating rat model. Proc Soc Exp Biol Med 217:345-350.

Anderson JW, Johnstone BM, and Cook-Newell ME (1995). Meta-analysis of the effects of soy protein intake on serum lipids (see comments). N Engl J Med 333:276-282.

Arjmandi BH, Birnbaum R, Goyal NV, Getlinger MJ, Juma S, Alekel L, Hasler CM, Drum ML, Hollis BW, and Kukreja SC (1998). Bone-sparing effect of soy protein in ovarian hormone-deficient rats is related to its isoflavone content. Am J Clin Nutr 68:1364S-1368S.

Ashby J, Tinwell H, Soames A, and Foster J (1999). Induction of hyperplasia and increased DNA content in the uterus of immature rats exposed to coumestrol. Environ Health Perspect 107:819-822.
Axelson M, Kirk DN, Farrant RD, Cooley G, Lawson AM, and Setchell KDR (1982). The identification of the weak oestrogen equol (7-hydroxy-3-[4'-hydroxyphenyl]chroman) in human urine. Biochem J 201:353-357.

Axelson $M$ and Setchell KDR (1980). Conjugation of lignans in human urine. FEBS Lett 122:49-53.

Axelson M and Setchell KDR (1981). The excretion of lignans in rats: Evidence for an intestinal bacterial source for this new group of compounds. FEBS Lett 123:337-342.

Axelson M, Sjovall J, Gustafsson BE, and Setchell KDR (1984). Soya: A dietary source of the non-steroidal oestrogen equol in man and animals. J Endocrinol 102:49-56.

Baraldi P, Spalluto G, Cacciari B, Romangnoli R, and Setchell KDR (1999). Chemical synthesis of [13C]Daidzein. J Med Food 2:99-102.

Barkley MS, Lasley BL, Thompson MA, and Shackleton CHL (1985). Equol: A contributor to enigmatic immunoassay measurements of estrogen. Steroids 46:587-608.

Barnes S, Grubbs C, Setchell KDR, and Carlson J (1990). Soybeans inhibit mammary tumors in models of breast cancer. Prog Clin Biol Res 347:239-253.

Barnes S, Peterson G, Grubbs C, and Setchell KDR (1994). Potential role of dietary isoflavones in the prevention of cancer. Adv Exp Med Biol 354:135-147.

Barnes S and Peterson TG (1995). Biochemical targets of the isoflavone genistein in tumor cell lines. Proc Soc Exp Biol Med 208:103-108.

Bennetts HW, Underwood EJ, and Shier FL (1946). A specific breeding problem of sheep on subterranean clover pastures in Western Australia. Aust J Agric Res 22:131-138.

Bennick M, Thiagarajan D, Bourquin L, and Mayle J ( 1999). Dietary soy is associated with decreased cell proliferation rate and zone in colon mucosa of subjects at risk for colon cancer. Proceedings of the Third International Symposium on the Role of Soy in Preventing and Treating Chronic Disease. J Nutr 130 (Suppl).

Bickoff EM, Livingston AL, Hendrickson AP, and Booth AN (1962). Relative potencies of several estrogen-like compounds found in forages. Agric Food Chem 10:410-412.

Blair HC, Jordan SE, Peterson TG, and Barnes S (1996). Variable effects of tyrosine kinase inhibitors on avian osteoclastic activity and reduction of bone loss in ovariectomized rats. J Cell Biochem 61:629-637.

Boettger-Tong $\mathrm{H}$, Murthy L, Chiappetta C, Kirkland JL, Goodwin B, Adlercreutz H, Stancel GM, and Makela S (1998). A case of a laboratory animal feed with high estrogenic activity and its impact on in vivo responses to exogenously administered estrogens. Environ Health Perspect 106:369373.

Borriello SP, Setchell KD, Axelson M, and Lawson AM (1985). Production and metabolism of lignans by the human faecal flora. J Appl Bacteriol 58:37-43.

Brown NM, Wang J, Cotroneo MS, Zhao YX, and Lamartiniere CA (1998). Prepubertal genistein treatment modulates TGF-alpha, EGF and EGF- receptor mRNAs and proteins in the rat mammary gland. Mol Cell Endocrinol 144:149-165.

Brzozowski AM, Pike AC, Dauter Z, Hubbard RE, Bonn T, Engstrom O, Ohman L, Greene GL, Gustafsson JA, and Carlquist M (1997). Molecular basis of agonism and antagonism in the oestrogen receptor. Nature 389:753-758. 
Butcher RL, Collins WE, and Fugo NW (1974). Serum concentration of $\mathrm{LH}, \mathrm{FSH}$, prolactin, progesterone and estradiol17 beta throughout the 4-day estrous cycle of the rat. Endocrinology 94:1704-1708.

Cassidy A, Bingham S, and Setchell KDR (1994). Biological effects of a diet of soy protein rich in isoflavones on the menstrual cycle of premenopausal women (see comments). Am J Clin Nutr 60:333-340.

Constantinou Al, Mehta RG, and Vaughan A (1996). Inhibition of $\mathrm{N}$-methyl-N-nitrosourea-induced mammary tumors in rats by the soybean isoflavones. Anticancer Res 16:3293-3298.

Coward L, Barnes NC, Setchell KDR, and Barnes S (1993). Genistein and daidzein, and their $\beta$-glycosides conjugates: Anti-tumor isoflavones in soybean foods from American and Asian diets. J Agric Food Chem 41:1961-1967.

Crouse JR 3rd, Morgan T, Terry JG, Ellis J, Vitolins M, and Burke GL (1999). A randomized trial comparing the effect of casein with that of soy protein containing varying amounts of isoflavones on plasma concentrations of lipids and lipoproteins. Arch Intern Med 159:2070-2076.

Dalu A, Haskell JF, Coward L, and Lamartiniere CA (1998). Genistein, a component of soy, inhibits the expression of the EGF and ErbB2/Neu receptors in the rat dorsolateral prostate. Prostate 37:36-43.

Day AJ, DuPont MS, Ridley S, Rhodes M, Rhodes MJ, Morgan MR, and Williamson G (1998). Deglycosylation of flavonoid and isoflavonoid glycosides by human small intestine and liver beta-glucosidase activity. FEBS Lett 436:71-75.

Drane H, Patterson D, Roberts B, and Saba N (1975). The chance discovery of oestrogenic activity in laboratory rat cake. Food Cosmetics Toxicol 13:491-492.

Eldridge A (1982). Determination of isoflavones in soybean flours, protein concentrates and isolates. J Agric Food Chem 30:353-355.

Eldridge A and Kwolek W (1983). Soybean isoflavones: Effects of environment and variety on composition. J Agric Food Chem 31:394-396.

Evans BA, Griffiths K, and Morton MS (1995). Inhibition of 5 alpha-reductase in genital skin fibroblasts and prostate tissue by dietary lignans and isoflavonoids. J Endocrinol 147: 295-302.

Food and Drug Administration (1999). FDA Talk Paper: FDA approves new health claim for soy protein and coronary heart disease. Available at http://www.fda.gov/bbs/topics/ ANSWERS/ANS00980.html. Accessed March 26, 2001.

Franke A, Custer L, Cerna C, and Marala K (1995). Rapid HPLC analysis of dietary phytoestrogens from legumes and from human urine. Proc Soc Exp Biol Med 208:18-26.

Fritz WA, Coward L, Wang J, and Lamartiniere CA (1998). Dietary genistein: Perinatal mammary cancer prevention, bioavailability and toxicity testing in the rat. Carcinogenesis 19:2151-2158.

Harrison E, Adjei A, Ameho C, Yamamoto S, and Kono S (1998). The effect of soybean protein on bone loss in a rat model of postmenopausal osteoporosis. J Nutr Sci Vitaminol (Tokyo) 44:257-268.

Helferich W, Hsieh CY, and Santell R (1998). Paradoxical effects of the phytoestrogen genistein on growth of estrogendependent human breast cancer cells in vitro and in vivo. In: Dunaif GE, Olin SS, Scimeca J, and Thomas JA, editors.
Human diet and endocrine modulation: Estrogenic and androgenic effects. Washington, DC: ILSI Press, 166-179.

Ishida H, Uesugi T, Hirai K, Toda T, Nukaya H, Yokotsuka K, and Tsuji K (1998). Preventive effects of the plant isoflavones, daidzin and genistin, on bone loss in ovariectomized rats fed a calcium-deficient diet. Biol Pharm Bull 21:62-66.

Jenkins DJA, Kendall CWC, Garsetti M, Rosenberg-Zand RS, Jackson C-J, Agarwal S, Rao AV, Diamandis EP, Parker T, Faulkner D, Vuksan V, and Vidgen E (2000). Effect of soy protein foods on low-density lipoprotein oxidation and ex vivo sex hormone receptor activity: A controlled crossover trial. Metabolism 49:537-543.

Kapiotis S, Hermann M, Held I, Seelos C, Ehringer H, and Gmeiner BM (1997). Genistein, the dietary-derived angiogenesis inhibitor, prevents LDL oxidation and protects endothelial cells from damage by atherogenic LDL. Arterioscler Thromb Vasc Biol 17:2868-2874.

Kim H, Peterson TG, and Barnes S (1998). Mechanisms of action of the soy isoflavone genistein: Emerging role for its effects via transforming growth factor beta signaling pathways. Am J Clin Nutr 68:1418S-1425S.

Kirk EA, Sutherland P, Wang SA, Chait A, and LeBoeuf RC (1998). Dietary isoflavones reduce serum cholesterol and atherosclerosis in C57BL/6 mice but not LDL receptordeficient mice. J Nutr 128:954-959.

Knuckles BE, deFremery D, and Kohler GO (1976). Coumestrol content of fractions obtained during wet processing of alfalfa. J Agric Food Chem 24:1177-1180.

Kuiper GG, Lemmen JG, Carlsson B, Corton JC, Safe SH, van der Saag PT, van der Burg B, and Gustafsson JA (1998a). Interaction of estrogenic chemicals and phytoestrogens with estrogen receptor beta. Endocrinology 139:4252-4263.

Kuiper GGJM, Nilsson S, and Gustaffson J-A (1998b). Characteristics and function of the novel estrogen receptor- $\beta$. In: Hormones and signaling, vol 1. New York: Academic Press, 89-112.

Lamartiniere C and Holland M (1992). Neonatal diethylstilbesterol prevents spontaneously developing mammary tumors. In: Li J, Nandi S, Li S, editors. Proceedings of the First International Symposium on Hormonal Carcinogenesis. New York: Springer Verlag, 305-308.

Lamartiniere CA, Moore J, Holland M, and Barnes S (1995a). Neonatal genistein chemoprevents mammary cancer. Proc Soc Exp Biol Med 208:120-123.

Lamartiniere CA, Moore JB, Brown NM, Thompson R, Hardin MJ, and Barnes S (1995b). Genistein suppresses mammary cancer in rats. Carcinogenesis 16:2833-2840.

Lamartiniere CA, Murrill WB, Manzolillo PA, Zhang JX, Barnes S, Zhang X, Wei H, and Brown NM (1998a). Genistein alters the ontogeny of mammary gland development and protects against chemically-induced mammary cancer in rats. Proc Soc Exp Biol Med 217:358-364.

Lamartiniere CA, Zhang JX, and Cotroneo MS (1998b). Genistein studies in rats: Potential for breast cancer prevention and reproductive and developmental toxicity. Am J Clin Nutr 68:1400S-1405S.

Madani S, Lopez S, Blond JP, Prost J, and Belleville J (1998). Highly purified soybean protein is not hypocholesterolemic in rats but stimulates cholesterol synthesis and excretion and reduces polyunsaturated fatty acid biosynthesis. J Nutr 128: 1084-1091. 
Makela S, Poutanen M, Lehtimaki J, Kostian ML, Santti R, and Vihko R (1995a). Estrogen-specific 17 betahydroxysteroid oxidoreductase type 1 (E.C. 1.1.1.62) as a possible target for the action of phytoestrogens. Proc Soc Exp Biol Med 208:51-59.

Makela S, Santti R, Salo L, and McLachlan JA (1995b). Phytoestrogens are partial estrogen agonists in the adult male mouse. Environ Health Perspect (103 Suppl) 7:123-127.

Makela SI, Pylkkanen LH, Santti RS, and Adlercreutz H (1995c). Dietary soybean may be antiestrogenic in male mice. J Nutr 125:437-445.

Mathieson R and Kitts WD (1980). Binding of phytoestrogen and estradiol $17 \beta$ by cytoplasmic receptors in the pituitary gland and hypothalamus of the ewe. J Endocrinol 85:317325.

Morton MS, Wilcox G, Wahlqvist ML, and Griffiths K (1994). Determination of lignans and isoflavonoids in human female serum following dietary supplementation. J Endocrinol 142: 251-259.

Murphy PA (1982). Phytoestrogen content of processed soybean products. Food Technol 43:60-64.

Murphy PA, Farmakelidis E, and Johnson L (1982). Isoflavone content of soya-based laboratory animal diets. Food Chem Toxicol 20:315-317.

Murrill WB, Brown NM, Zhang JX, Manzolillo PA, Barnes S, and Lamartiniere CA (1996). Prepubertal genistein exposure suppresses mammary cancer and enhances gland differentiation in rats. Carcinogenesis 17:1451-1457.

Nagel SC, vom Saal FS, and Welshons WV (1998). The effective free fraction of estradiol and xenoestrogens in human serum measured by whole cell uptake assays: Physiology of delivery modifies estrogenic activity. Proc Soc Exp Biol Med 217:300-309.

Nequin LG, Alvarez J, and Schwartz NB (1979). Measurement of serum steroid and gonadotropin levels and uterine and ovarian variables throughout 4 day and 5 day estrous cycles in the rat. Biol Reprod 20:659-670.

Pike AC, Brzozowski AM, Hubbard RE, Bonn T, Thorsell AG, Engstrom O, Ljunggren J, Gustafsson JA, and Carlquist M (1999). Structure of the ligand-binding domain of oestrogen receptor beta in the presence of a partial agonist and a full antagonist. EMBO J 18:4608-4618.

Pollard M and Luckert PH (1997). Influence of isoflavones in soy protein isolates on development of induced prostaterelated cancers in L-W rats. Nutr Cancer 28:41-45.

Ruiz-Larrea MB, Mohan AR, Paganga G, Miller NJ, Bolwell GP, and Rice-Evans CA (1997). Antioxidant activity of phytoestrogenic isoflavones. Free Radic Res 26:63-70.

Sadowska-Krowicka H, Mannick EE, Oliver PD, Sandoval M, Zhang XJ, Eloby-Childess S, Clark DA, and Miller MJ (1998). Genistein and gut inflammation: Role of nitric oxide. Proc Soc Exp Biol Med 217:351-357.

Salzman A, Preiser J-C, Setchell KDR, and Szabo C (1999). Isoflavone-mediated inhibition of tyrosine kinase: A novel anti-inflammatory approach. J Medicinal Food 2:179-181.

Setchell KDR (1998). Phytoestrogens: The biochemistry, physiology, and implications for human health of soy isoflavones. Am J Clin Nutr 68:1333S-1346S.

Setchell KDR and Adlercreutz H (1988). Mammalian lignans and phytoestrogens. Recent studies on their formation, me- tabolism and biological role in health and disease. In: Rowland IR, editor. Role of the gut flora in toxicity and cancer. London: Academic Press, 315-334.

Setchell KDR, Borriello SP, Hulme P, Kirk DN, and Axelson M (1984). Nonsteroidal estrogens of dietary origin: possible roles in hormone-dependent disease. Am J Clin Nutr 40:569 578.

Setchell KDR and Cassidy A (1999). Dietary isoflavones: Biological effects and relevance to human health. J Nutr 129:758S-767S.

Setchell KDR, Gosselin SJ, Welsh MB, Johnston JO, Balistreri WF, Kramer LW, Dresser BL, and Tarr MJ (1987a). Dietary estrogens: A probable cause of infertility and liver disease in captive cheetahs. Gastroenterology 93:225-233.

Setchell KDR, Welsh M, and Lim C (1987b). HPLC analysis of phytoestrogens in soy protein preparations with ultraviolet, electrochemical, and thermospray mass spectrometric detection. J Chromatogr 385:267-274.

Setchell KDR, Zimmer-Nechemias L, Cai J, and Heubi JE (1997). Exposure of infants to phyto-oestrogens from soybased infant formula (see comments). Lancet 350:23-27.

Setchell KDR, Zimmer-Nechemias L, Cai J, and Heubi JE (1998). Isoflavone content of infant formulas and the metabolic fate of these phytoestrogens in early life. Am J Clin Nutr 68:1453S-1461S.

Sharma OP, Adlercreutz H, Strandberg JD, Zirkin BR, Coffey DS, and Ewing LL (1992). Soy of dietary source plays a preventive role against the pathogenesis of prostatitis in rats. J Steroid Biochem Mol Biol 43:557-564.

Sheiber MD, Setchell KDR, Liu JH, Subbiah MTR, and Rebar RW (In press, 2001). Dietary soy supplementation reduces LDL-oxidation and bone turnover in healthy postmenopausal women. Menopause.

Thiagarajan DG, Bennink MR, Bourquin LD, and Kavas FA (1998). Prevention of precancerous colonic lesions in rats by soy flakes, soy flour, genistein, and calcium. Am J Clin Nutr 68:1394S-1399S.

Thigpen JE, Setchell KD, Ahlmark KB, Locklear J, Spahr T, Caviness GF, Goelz MF, Haseman JK, Newbold RR, and Forsythe DB (1999a). Phytoestrogen content of purified, open- and closed-formula laboratory animal diets. Lab Anim Sci 49:530-536.

Thigpen JE, Setchell KD, Goelz MF, and Forsythe DB (1999b). The phytoestrogen content of rodent diets (letter). Environ Health Perspect 107:A182-183.

Tikkanen MJ, Wahala K, Ojala S, Vihma V, and Adlercreutz H (1998). Effect of soybean phytoestrogen intake on low density lipoprotein oxidation resistance. Proc Natl Acad Sci USA 95:3106-3110.

Tovar-Palacio C, Potter SM, Hafermann JC, and Shay NF (1997). Intake of soy protein and soy protein extracts influences lipid metabolisn and hepatic gene expression in gerbils. J Nutr 128:839-842.

Walter E (1941). Genistein (an isoflavone glucoside) and its aglucone, genistin, from soybeans. J Americal Oil Chem Soc 63:3273-3276.

Walz E (1931). Isoflavone: A Saponin glucoside in soya. Justus Liebigs Ann Chem 489:118-155. 
Wang HJ and Murphy PA (1994). Isoflavone content in commercial soybean foods. J Agric Food Chem 42:16661673.

Weber KS, Setchell KDR, Stocco DM, and Lephart ED (In press, 2001). Dietary soy-phytoestrogens decrease testosterone levels and prostate weight, without altering $\mathrm{LH}$, prostate 5-alpha reductase or testicular StAR levels in adult male Sprague-Dawley rats. J Endocrinol.

Wei H, Bowen R, Cai Q, Barnes S, and Wang Y (1995). Antioxidant and antipromotional effects of the soybean isoflavone genistein. Proc Soc Exp Biol Med 208:124-130.
Whitten PL, Lewis C, Russell E, and Naftolin F (1995). Potential adverse effects of phytoestrogens. J Nutr 125: 771S-776S.

Whitten PL and Naftolin F (1992). Effects of a phytoestrogen diet on estrogen-dependent reproductive processes in immature female rats. Steroids 57:56-61.

Whitten PL, Russell E, and Naftolin F (1992). Effects of a normal, human-concentration, phytoestrogen diet on rat uterine growth. Steroids 57:98-106. 